\title{
THE ANGLO-SAXON PERIOD OF ENGLISH LAW
}

We find the proper starting point for the history of English law in what are known as Anglo-Saxon times. Not only does there seem to be no proof, or evidence of the existence of any Celtic element in any appreciable measure in our law, but also, notwithstanding the fact that the Roman occupation of Britain had lasted some four hundred years when it terminated in A. D. 4Io, the last word of scholarship does not bring to light any trace of the law of Imperial Rome, as distinct from the precepts and traditions of the Roman Church, in the earliest AngloSaxon documents. That the written dooms of our kings are the purest specimen of pure Germanic law, has been the verdict of one scholar after another.

Professor Maitland tells us that: "The Anglo-Saxon laws that have come down to us (and we have no reason to fear the loss of much beyond some dooms of the Mercian Offa) are best studied as members of a large Teutonic family. Those that proceed from the Kent and Wessex of the seventh century are closely related to the Continental folk-laws. Their next of kin seem to be the Lex Saxonum and the law's of the Lombards." I Whatever is Roman in them is ecclesiastical, the system which in course of time was organized as the Canon law. Nor are there in England any traces of any Romani who are being suffered to live under their own law by their Teutonic rulers. As Dean Church has said: "Out of their own customs, their own strong and brave notions of right, their own spontaneous efforts after a reasonable and suitable order of life, unaffected by foreign schooling as by imitation of foreign ways, losing, perhaps, some of the benefits of foreign experience, the chiefs of the new English Kingdoms worked out principals and institutions which were to be the foundations of a political organization as solid, as elastic, as enduring as that of Rome."2 Our laws, as they exist to-day, have been formed in the main from a stock of Teutonic customs, with some additions of matter, and considerable additions or modifications of form received directly, or indirectly, from the Roman system; and both the Germanic

1 Encyc. Brit. (1902) English Law, Vol. XXVIII, p. 247.

2 Epochs of English History, Beginning of the Middle Ages, pp. 63-65. 
and Romanic elements have been constituted and reinforced at different times and from different sources. ${ }^{3}$

On the other hand, we cannot afford to pass by Anglo-Saxon times, and make our starting point the Norman Conquest, because it was no part of William the Conqueror's wish or policy to supersede the laws and customs of Britain, although no doubt there was a sudden and masterful importation of Norman customs, and "institutions which have nowadays the most homely and English appearance may nevertheless be ultimately connected, through the customs of Normandy, with the system of government elaborated in the latter centuries of the Roman Empire."4 Of written law the Normans had none of their own making; and there was none which they could readily borrow from their French neighbors, although it is now generally admitted that, for at least half a century before the Battle of Hastings, the Normans were Frenchmen, French in their language, and French in their law. ${ }^{5}$

William the Conqueror abolished neither the laws and customs of the Anglo-Saxons, nor their existing courts and procedures, although modifications and changes in both speedily followed the Conquest. But even in the first half of the twelfth century an expounder of the law of England had still to say that the country was divided between the Wessex law, the Mercian law, and the Danish law, although he had also to point out that the law of the King's own court stood apart from and above all partial systems. ${ }^{6}$ As the history of Roman law may be said to begin with the code known as the Twelve Tables, so for the history of our own law, we may very well take as our starting point a code, namely, the Code of Ethelbert, King of the Kentish men, when about the year A. D. 600 , by the counsel of his wisemen, he caused the laws of his people to be set down in writing. But Ethelbert had just been converted to the christian faith by Roman missionaries. His laws are not primitive in any absolute sense of the term. They are christian. The very first sentence of his code, the first recorded utterance of English law, mentions churches, bishops, priests, deacons, clerks; and this change of faith means the

\footnotetext{
${ }^{3}$ Pollock and Maitland, Hist. Eng. Law (2d ed.) Vol. I, p. xxx.

4 Ibid., p. xxxiii.

Ibid., pp. 65-66.

- Professor Maitland; English Law, Encyc. Brit. (1902) Vol. XXVIII, p. 247.
} 
influence of the old civilized world upon the new barbaric world. Of the days of its heathenry, Germanic law has no written memorials. ${ }^{7}$

Ethelbert's code consists of ninety brief sentences. Two will serve as samples: "If one man strikes another with the fist on the nose-three shillings." "If the eye be struck out, let boot [i. e. amends] be made with fifty shillings." If a concrete case were to occur, no doubt the wise men of Kent would be ready with a doom; but when asked for general rules these ninety were all they could call to mind. ${ }^{8}$

It is a picturesque starting point which we have selected for our legal history, not only because in Anglo-Saxon times English laws were being written in English, which they long ceased to be after the Conquest, but because the reign of Ethelbert overlapped the reign of Justinian, the great emperor of the East, with whose compilations the history of Roman law may in a sense be said to close; and it was, perhaps, in imitation of Justinian that King Ethelbert set his hand to putting the laws of his people into writing. As Professor Maitland says: "English law begins to speak just when Roman law has spoken what will, in a certain sense, be its final words." "9

Following the Code of Ethelbert come a number of other Anglo-Saxon codes, one from Ine, King of the West Saxons in the middle of the seventh century; then after two hundred years the laws of Alfred, which show that, though during the last two centuries some new legal ideas have emerged, still the core of the law is what it was-what can be put in writing is for the most part a tariff of the sums that must be paid when deeds of violence are done. ${ }^{10}$ Then legislation becomes more common. The tenth century and the first years of the eleventh are illustrated by laws of Edward, Etheltan, Edmund, Edgar, and Ethelred; and the scene ends with the lengthy and luminous Code of Canute the Dane. In addition to these we have a few short statements of legal or customary rules coming to us, not from lawgivers, but from presumably. learned men-little formularies and so forth which were transcribed along with the laws, and have been slowly disengaged from them by the skill of recent editors. ${ }^{11}$

\footnotetext{
7 Professor Maitland, Social England (ed. Traill) Vol. I, p. 166.

8 Ibid., p. I67.

${ }^{9}$ Ibid., p. 165

10 Ibid., pp. 167-168.

11 Laws of the Anglo-Saxons, 200 QUART. REv. I40-I4I.
} 
As Professor Maitland tells us, the Code of King Canute shows that by the eleventh century the whole economic and political structure of society was undergoing a great change, which may be concisely described by saying that tribalism was giving place to feudalism. "Had Canute's successors been his equal in vigour and wisdom, perhaps the change might have been consummated peacefully, and by means of written laws which we might now be reading. As it was there came to the throne the holy, but imbecile Edward. In after days he won not only the halo of the saint, to which he may have been entitled, but the fame, to which he certainly was not entitled, of having been a great legislator. In the minster that he reared, king after king made oath to observe the laws of the Confessor. So far as we know he never made a law. Had he made laws, had he even made good use of those that were already made, there might have been no Norman Conquest of England. But then had there been no Norman Conquest of England, Edward would never have gained his fictitious glories. As it was, men looked back to him as the last of the English kings of the English-for of Harold, who had become the conquered usurper, there could be no talk-and galled by the yoke of their French masters, they sighed for Saint Edward's law, meaning the law that had prevailed in a yet unvanquished England."12

Now all these enacted and written laws of our Anglo-Saxon forefathers, representing though they do some four and a half centuries, might all be handsomely printed in 150 octavo pages. Life, with its relations and transactions was of course simple, but, apart from that, "in ancient days if the legislator can maintain the peace, suppress violence and theft, and keep vengeance within moderate bounds, he is well satisfied: he will not be at pains to enact a law of contract or of inheritance, a law of husband and wife, a law of landlord and tenant. All this can safely be left to unwritten tradition. . . . The laws of the folk, the 'folk-right'-'law' is one of the words which the Danes bring with them-is known to the men of the folk-but more especially to the old and wise. The freemen or the free landowners of the hundred are in duty bound to frequent the 'moot,' or Court, of the hundred, to declare the law, and to make the

12 Social England, op. cit., pp. 168-r69. 
dooms."13 The extant collections of Anglo-Saxon laws do not give us anything like a complete view of the legal or juridical institutions of the time. They assume knowledge on the reader's part of an indefinite mass of received custom and practice. They are mere superstructures on a much larger basis of customs. ${ }^{14}$

We must say a few words on the general conditions, customs, and practices of Anglo-Saxon times, so far as known to us, which have a special bearing upon law and procedure. As to the condition of persons we find free men and slaves, and among free men some are lords, and some dependents or followers of lords; and this pervading division of free persons into lords and men, together with the King's position as general overlord, combined at a later time with the prevalence of dependent land tenures, to form the more elaborate arrangements and theories of mediæval feudalism. But it does not seem possible to assign any time in English history when some free men did not hold land from their personal lords, nor yet to assign the time when this became a normal state of things. It was, however, the work of the century succeeding the Norman Conquest to establish the theory, that all land must be "held of" some one, as a fixed principle of English law..$^{15}$ Moreover we find distinctions of rank among freemen, which, although not amounting to fundamental differences of condition and not always rigidly fixed, had more or less definite legal incidents. The ordinary freeman is a "ceorl" or churl; the noble by birth an "eorl." But the official term of rank which we find in and after Alfred's time is "thegn." Originally a thegn is a household officer of some great man, eminently and especially of the King. From the tenth century to the Conquest, however, thegnship did not necessarily imply an officer, but it was a social condition above that of the churl, carrying with it both privileges and customary duties. As to unfree men, slavery, personal slavery, and not merely serfdom or villeinage consisting mainly in attachment to the soil, existed and was fully recognized in England until the twelfth century. As to serfdom it would seem to have been much more of a personal bondage, and less involved with occupation of particular land, before the Norman Conquest than after. ${ }^{18}$

18 Ibid., p. 170.

14 Pollock and Maitland, op. cit., pp. 26-27.

15 Ibid., pp. 29-3I ; cf. Essajs in Anglo-Saxon Law (Boston, 1905) p. IIg.

16 Pollock and Maitland, op. cit., pp. 33, 35, 37. 
The ordinary Anglo-Saxon courts of public justice were the County Court and the Hundred Court, of which the County Court was appointed to be held twice a year, and the Hundred Court every four weeks. We have no evidence that any lesser public court existed than the hundred. ${ }^{17}$ The smallest administrative division recognized in the arrangements of our mediæval constitution was the hundred. The question of its origin is one of the most obscure points of history. ${ }^{18}$ These courts, which had jurisdiction over all kinds of cases, were open-air meetings of the freemen who were bound to attend them, the "suitors" as they are called in the terms of Anglo-Norman and later medieval law. Thus as Bishop Stubbs says, "Judicature is among the AngloSaxons purely a matter of local or self-government." These courts were strictly representative bodies, and their judicial authority was from beneath and not from above: their jurisdiction was not derived from the King, although within historical times he nominated the sheriff who, with the bishop and ealdorman, presided. In each of them the township was represented by the reeve and four men, while the presence of the thanes, the parish priests, the bishop, sheriff, and ealdorman completed the united body. The sheriff represented the judicial element in the presiding trio, the bishop the religious sanction, the ealdorman the national recognition; ${ }^{19}$ but the suitors themselves were the judges, their function being to declare the law as assessors of the sheriff. The presence of the bishop is significant of the wellknown peculiarity of the Anglo-Saxon period; namely, that secular and ecclesiastical courts were not sharply separated, and the two jurisdictions were hardly distinguished. The bishop sat in the County Court, and probably was often the only member of the court who possessed any learning, or any systematic training in public affairs. ${ }^{20}$ Never, perhaps, in any country were church and state more closely united than they were in Anglo-Saxon times in England. Not only did the bishop sit in the courts in every county with the sheriff to declare the divine law, as the sheriff did the secular law; but the prelates, the bishops, and

\footnotetext{
17 Pollock and Maitland, op. cit., p. 42.

${ }^{18}$ Medley, English Constitutional History (2d ed.) pp. 318, 325-326.

19 From the time of Egbert (A. D. 802-839) the earldorman was a magistrate or viceroy appointed by the King and his Witan, more especially the governor of a shire or large district. Tasw.-Langmead, Constitutional History (4th ed.) p. 29.

20 Pollock and Maitland, op. cit., p. 40.
} 
abbots formed, as wise men qualified by their spiritual office to be counsellors, a very large proportion of the Witenagemot, the ruling council of the kingdom. ${ }^{21}$

Ecclesiastical causes were themselves tried in the folk-mote, the bishops and clergy by their influence there being able to secure fair treatment, and not yet requiring, as was granted by William the Conqueror, a separation of jurisdiction, the expulsion of the bishop from his seat in the County Court, and the consequent withdrawal of ecclesiastical causes into spiritual courts. That, for spiritual offences, the bishop always had his court may, Bishop Stubbs considers, be regarded as certain; but, until the Conquest, ecclesiastical causes, as distinct from spiritual ones, were, it is believed, tried in the courts of the people.

There was no regular way of appealing from the judgments of these popular courts. The King might, of course, act as arbitrator, or give advice to his immediate dependants to compromise their suits. He was bound by his office to exercise some general supervision over the working of the Hundred and the County Courts. He was represented by the sheriff; he might send out commissioners to enquire and report how justice was done, although he could not interfere with the actual decisions. The efficiency of these powers varied, no doubt, according to the king's means and capacity for exercising them $;^{22}$ but his judicial functions consisted of a special and reserved power which a man might invoke only if he had failed to get his cause heard in the jurisdiction of his own hundred or county. Such a thing might happen not from ill-will or corruption on the part of any public officer, but from a powerful lord protecting offenders who were his men. ${ }^{23}$

As to procedure in the County and Hundred Courts the forms were sometimes complicated; always stiff and unbending. We must not picture to ourselves these old courts, as courts of equity, where the "natural man" administered an informal "law of nature." "For one thing the law of the natural man is supernatural law, a law which deals with miracles and portents. But then again it is exceedingly formal. It is a law of procedure.

\footnotetext{
${ }^{21}$ Stubbs, Lectures on Early English History (ed. Hassall, I906) pp. 243-245.

22 Bowker, Alfred the Great (London. Adam and Charles Black, I899) pp. 2I3-3I4.

${ }^{23}$ Pollock and Maitland, op. cit., p. 40.
} 
The right word must be said without slip or trip, the due ceremonial must be punctiliously performed, or the whole transaction will go for naught."24

The need of a hard and fast rule in judicial proceedings was very soon felt. "Suitors in the early age of regular justice are highly suspicious of personal favour and caprice, and will not hear of any room for discretion. As they apprehend it, a Court once allowed to relax the customary forms could make of the law itself whatever its members and managers for the time being pleased." This is one source of formalism in procedure. Another is the prehistoric belief in symbolic magic. "It is assumed that words have in themselves an operative virtue which is lost if any one word is substituted for another." But this regard for form was not universal. "When the members of the :Court (originally the whole of the assembled free men) had the means of acting on their own immediate knowledge, they could act without any form at all." It was not till the fact was disputed, that "our ancestors' minds were at once filled with deep distrust of human testimony, and entire disbelief in the power of human judgment to discover the truth, perhaps also in the existence of any impartial will to discover it. . . - It was a great and a true word Thering spoke when he said: 'Form is the sworn foe of caprice; she is Freedom's twin-sister.".25

In such cases of disputed fact, oath by oath-helpers or compurgators was the primary mode of proof: an oath going not to the truth of specific fact, but to the justice of the claim or defence as a whole. The number of persons required so to swear varied according to the nature of the case and the rank of the person concerned. Failing oath-helpers, an accused person had to go to one of the forms of ordeal. ${ }^{26}$ But first it has to be adjudged that one party or the other to the litigation is to make his proof. It is not a question of adducing evidence. Evidence with us is offered with a view to leading a judge or jury to some inference of fact which may determine, or help to determine, the decision of the case as a whole. There are no archaic rules of evidence; the conception of adducing evidence is unknown, excepting in the case of transaction witnesses, the oath de visu et auditu as it is called in the Leges Henrici..27

24 Social Engiand, op. cit., p. 171.

${ }^{25}$ Sir F. Pollock, Genius of the Common Law, pp. 15, 16, 2r.

${ }^{26}$ Pollock and Maitland, op. cit., Vol. I, p. 39.

27 Circa A. D. III8. 
But this was simply a conjuratory oath to a particular fact, altogether different from the oath of evidence now in use as a promise to speak truth on questions put to you. "In the name of Almighty God," it ran, "as I stand here for N. in true witness, unbidden and unbought (sine prece et pretio), so I with my eyes oversaw and with my ears overheard that which I with him say."28 It can be gathered from the "dooms," as the laws of the Anglo-Saxon kings were called, that all legal transactions were required to be done before some sworn men of the hundred, so that they might be ready to try any subsequent disputes. If necessity arose these witnesses were sworn in the Hundred or Shire Court, and practically decided the dispute on their own knowledge. ${ }^{29}$ In old times proof was not an attempt to convince the judges. It was an appeal to the supernatural, and very commonly a unilateral act. The archaic proof comes after judgment, not before. It is adjudged that John or Peter is to make his proof. Not that he is bound to make it, as a modern student is tempted to think, but that he is entitled to make it, that he has the prerogative of proving, as they said in comparatively modern Scotch practice. Formal affirmation by the plaintiff generally reinforced by a "suit" of fellow-swearers has been the first step. It has been met by denial, a formal denial which, on pain of failure, had to traverse every point of the plaintiff's assertion word for word. The court awards proofs to one or the other party and then he is in possession of the case. ${ }^{30}$ It is adjudged, for example, in an action for debt, that the defendant do prove his assertion that he owes nothing by his own oath, and the oath of a certain number of compurgators or oath-helpers. The defendant must then solemnly swear that he owes nothing, and his oath-helpers must swear that his oath is clean and unperjured. If they safely get through this ceremony, punctually repeating the right formula, there is an end to the case; the plaintiff, if he is hardy enough to go on, can only do so by bringing a new charge-a criminal charge of perjury. ${ }^{31}$

As to the origin of this procedure Professor Hobhouse tells us: "As the feud will not be waged by the individual claimant alone,

${ }^{28}$ Stubbs, Lectures on Early English History (ed. A. Hassell, 1906) p. I74.

${ }^{29}$ R. Storry Deans, Students' Legal History (2d ed.) p. 3.

30 Pollock, op. cit., pp. 17-20.

31 Maitland, Equity, p. 310; cf. Essays on Anglo-Saxon Law, pp. 186-188. 
but with the aid of all his kindred, so the Court will expect the kindred to come and take the oath along with him. Hence the institution of oath-helpers, the compurgators, who are in point of fact the fellow clansmen, all bound to the duty at this stage of swearing their friend out of the difficulty, just as before they were bound to help him out of it by arms. The compurgators are simply the clansmen fighting with spiritual weapons instead of carnal ones. Success in the cause will depend, not on the opinion formed by the Court as to the veracity of one side, or the perjury of the other, but on the ability of the parties to get the full number of compurgators required in formal correctness in taking the oath; and if both parties fulfil all conditions, and no further means are available for deciding between them, on certain rules as to the burden of proof." 32

"A very easy task this oath with oath-helpers may seem in our eyes. It is not so easy as it looks. In the first place ceremonial rules must be strictly observed; a set form of words must be pronounced; a slip, a stammer, will spoil all, and the adversary will win his cause. Besides it is common knowledge that those who perjure themselves are often struck dead, or reduced to the stature of dwarfs, or find that they cannot remove their hands from the relics they have profaned." 33

This process known in England as "waging one's law" lingered on through the Middle Ages, and much later in the "wager of law." But it rapidly became a farce as the reality of its meaning became lost. A man indicted under the Assizes of Clarendon and Northampton, ${ }^{34}$ at the King's suit, could not wage his law..$^{35}$ The origin of the expression "wager of law" seems to be due to the fact that "the accused gave pledges (vadia) to appear with his "oath-helpers" on a given day. Ultimately the compurgators became mere witnesses to character, and were not accepted in contradiction of manifest facts; and by the fourteenth century, or soon after, had given way to trial by jury on evidence. ${ }^{36}$ But wager of law was not formally abolished by statute until the year 1833 .

In matters of contract or conveyance, as we have indicated, witnesses were necessary to the validity of the transaction, and

${ }^{32}$ Morals in Evolution, Vol. I, p. I02; cf. Essays on Anglo-Saxon Law, pp. 297-298.

${ }^{33}$ Social England, op. cit., p. 286.

${ }^{34}$ A. D. 1164 ; A. D. 1176.

${ }^{35}$ Jenks, Short History of English Law, pp. 46-48.

${ }^{36}$ Encyc. of English Law, sub voce. 
probably these, or some of these, formed some of the compurgators. In cases of tort or crime, it is probable that witnesses of the affair (if any) would be included in the number of the compurgators called by the complainant or the defendant; but save to this extent, they seem to have been very much like witnesses to character. ${ }^{37}$

Oath being the normal mode of proof in cases about property, it was in certain circumstances and cases supplemented by resort to the ordeal. In later Anglo-Saxon times the ordeal seems to have been regarded as more especially reserved for serious crimes, or for persons of bad character. ${ }^{38}$ In no case could a man against whom lay a presumption of guilt, $e . g$., the man who was taken red-handed, or on whom the stolen property was found, wage his law. Before the Norman trial by battle had been introduced-which was another form of appeal to the supernatural powers-the only alternative for such a man was a resort to the ordeal, which was, in fact, to invoke a miracle. ${ }^{39}$

The usual forms of ordeal of which we read in England were sinking or floating in cold water, recovery within a limited time from the effect of plunging the arm into boiling water, or of handling red hot iron. Originally no doubt the appeal was to the god of water, or of fire as the case might be. The church objected, temporized, hallowed the obstinate heathen customs by the addition of christian ceremonies, and finally, but not until the thirteenth century, was strong enough to banish them. ${ }^{40}$ In I2I5 the Fourth Lateran Council forbade the clergy to take part in the ordeal. After this we hear no more in England of the ordeal as a legal process, though in much later days the popular belief that witches will swim, died hard, and many an old woman was put into the pond.

The form for the ordeal is interesting and we see in it how completely the institution was regarded as an ecclesiastical matter, and a solemn appeal to God as the righteous Judge; and so understand why the Conqueror by edict puts it entirely in the hands of the bishop: "Concerning the ordeal we enjoin by command of God and of the archbishop and all the bishops the fire is lighted in the church, and the church is closed to all but the mass priest and the person who is to go to the ordeal. A dis-

${ }^{37}$ R. Storry Deans, op. cit., p. 7.

ss Holdsworth, Hist. Eng. Law., Vol. II, p. 97.

39 Jenks, op. cit., pp. 46-47; cf. Essays on Anglo-Saxon Law, pp. 300-303.

to Bowker, op. cit., p. 216. 
tance is to be marked nine steps, according to the steps of the accused, from the mark to the stake on which the ordeal, $i$. e., the hot water or hot iron, is placed. The kettle that contains the water may be of iron or brass or lead or clay; the water is to bubble up before boiling, a stone is placed in the kettle. The culprit bares his hand; if the accusation requires simple purgation, it is enough if he plunge it up to his wrist; for a threefold one it must go in up to the elbow. Before the critical step is taken two men of each side are to go in and test whether the water is as hot as the rule enjoins; then let a certain number of each party go in and stand in a row along the sides of the church. These witnesses must be fasting. The priest is to sprinkle them with holy water, and let them taste it, and give them all the book and the crucifix to kiss."11

In the case of the ordeal of hot iron the order is even more minute. The service begins with benediction; the fire has been lighted and the iron laid thereon. After the beginning of the benediction the fire is not to be stirred; the service proceeds to the last collect, when that has been said, it is to be taken from the fire and put on the staple or stool, and there is to be solemn silence. "Let there be no other speaking within, except that they earnestly pray to Almighty God that He make manifest what is soothest; and let him go thereto, making the nine steps. At the first signal he must put his right foot on the staple, at the second the left foot, then grasp the iron at the third signal, and throw it forward, then hasten to the altar and have his hand covered and sealed to the third day. According to the state in which it shall be found on the third day, his guilt or innocence is proved." 42

It will be seen that this account of ritual makes no mention of the ordeal of sinking or swimming in cold water. Nor does it say anything of the ordeal known as "the accursed morsel." A piece of hard dry bread was specially consecrated by the priest. The accused first called on the Deity to make the break stick in his throat if he were guilty; and then proceeded to slowly eat the morsel. If he swallowed it freely he was innocent; but should he choke in any way he was guilty. The great Earl Godwin is said to have been choked in this way. ${ }^{48}$

It is hard for us to say how this ancient procedure worked in practice; hard to tell how easy it was to get oath-helpers who

11 Stubbs, op. cit., pp. 173-174.

12 Ibid.

4s R. Storry Deans, op. cit., p. 8. 
would swear falsely; hard to tell how much risk there was in an ordeal.4

The only way to bring an unwilling adversary before the court was to take something of his as security till he would attend to the demand, and practically the only things that could be taken without personal violence were cattle. Distress in this form was practised and also regulated from very early times. It was forbidden to distrain until right had been formally demanded-in court's time to the extent of three summonings-and refused. Thus, leave of the court was required, but the party had to act for himself as best he could. If distress failed to make the defendant appear, the only resource left was to deny the law's protection to the stiff-necked man who would not come to be judged by law. He might be outlawed. The offender was declared to be outside the protection of the laws he had broken; and being "out of the law" he became a "wolf's head" (caput lupinum) whom anyone could kill.s5 The device of judgment by default, which is familiar enough to us, was unknown, and probably would not have been understood. Final judgment when obtained, could in like manner not be directly enforced. The successful party had to see to gathering "the fruits of judgment," as we say, for himself. In case of continued refusal to do right according to the sentence of the court, he might take the law into his own hands; in fact wage war on his obstinate opponent. The ealdorman's aid, and ultimately the King's, could be invoked in such extreme cases as that of a wealthy man, or one backed by a powerful family, setting the law at open defiance. But this was an extraordinary measure analogous to nothing in the regular modern process of law. ${ }^{46}$

Such was, in outline, the procedure of courts of public jurisdiction in Anglo-Saxon times. It is certain that private courts of lords of various degrees, holding courts on their lands at which their tenants were entitled to seek justice in their own local affairs, and bound to attend that justice might be done to their fellows, were well established in England at the date of the Conquest. ${ }^{27}$

A. H. F. LEFroy.

Toronto, Canada.

(To be continued.)

44 Social England, op. cit., p. 287.

15 R. Storry Deans, op. cit., p. 9.

40 Bowker, op. cit., pp. 220-221.

47 Pollock and Maitland, op. cit., p. 43; cf. Essays on Anglo-Saxon Law, p. 50 . 